\title{
Educational Technology in Iranian High Schools: EFL Teachers' Attitudes, Perceived Competence, and Actual Use
}

\author{
Hasan Jahanban-Isfahlan, Nasrin Hadidi Tamjid, and Zohre Seifoori \\ Department of English, Tabriz Branch, Islamic Azad University, Tabriz, Iran \\ Correspondence should be addressed to Nasrin Hadidi Tamjid; nhadidi@iaut.ac.ir
}

Received 21 June 2017; Accepted 29 October 2017; Published 1 December 2017

Academic Editor: Gwo-Jen Hwang

Copyright (C) 2017 Hasan Jahanban-Isfahlan et al. This is an open access article distributed under the Creative Commons Attribution License, which permits unrestricted use, distribution, and reproduction in any medium, provided the original work is properly cited.

\begin{abstract}
It goes without saying that technology has influenced virtually all spheres of our lives, and teaching English as a foreign language (EFL) is not an exception to this rule. Also, teachers' undeniable and decisive role in the integration of technology into teaching is not to be taken a blind eye on. With this in mind, this study explored Iranian high school EFL teachers' attitudes toward, their perceived competency in, and their actual use of instructional technology in their classrooms. 120 randomly selected junior and senior high school Iranian EFL teachers filled out The Survey of High School EFL Teachers' Attitudes toward Computer Technology. Over 600 junior and senior high school students filled out Students' Questionnaire Surveying the Use of Educational Technology by English Teachers in Classrooms. The results indicated that even though Iranian teachers have an overall positive attitude toward (computer) technology, they are not sufficiently competent to use it in their classes, and this lack of competence may be one of the main barriers to the full use of technology in their classes.
\end{abstract}

\section{Introduction}

In the new millennium, technology has become a household term and all walks of approximately all societies avail themselves of it constantly in one way or another. It has become so prevalent that it is unrealistic and impractical to think and talk about this era without taking into consideration the diverse types of technology and their undeniable and huge impact on all spheres of our lives.

Education is one of those innumerable spheres and domains influenced by technology and will undoubtedly continue to do so. Teaching and learning English as a foreign language also is one of these subdomains experiencing the introduction and use of various types of technologies in recent years. The use of technology in this domain has flourished so profoundly that according to Stickler and Shi [1], presently, we are witnessing a trend toward more ecological approaches to Computer Assisted Language Learning (CALL) research, instead of the experimental researches which prevailed in its beginning years; therefore, researchers are considering CALL as a "normalised" teaching and learning practice and an attempt to probe what takes place actually when learners learn a language assisted by technology making use of novel or recently adapted methods.

However, as noted in the World Education Report (UNESCO, 1998a), education worldwide is facing a significant challenge in preparing students and teachers for "our future 'knowledge-based' society" during a time when most teachers are not prepared to use ICT, and a large number of present school buildings, even in the most developed countries, are not equipped to use the new information and communication technologies [2].

Needless to say, when studying the requirements for successful integration of learning technologies into classrooms, the crucial role of the teacher in the classroom is not to be underestimated. The end point of educational change, that is, classroom change lies in the teachers' hands. The reason is that when the classroom door is closed and nobody else is around, it is the classroom teacher who can make a selection and teach almost any curriculum he or she thinks is appropriate, regardless of reforms, innovations, and public examinations [3]. 
In his much cited article which explored the attitudes of high school English as a foreign language (EFL) teachers in Syria toward ICT, Albirini [4] stated that using technology in Syrian schools was not guided by research, which has frequently been the case in most countries all over the world. $\mathrm{He}$ adds, "In particular, the technology implementation plans seem to be lacking consideration of teachers' reaction to the new tools. Such inattention to the end-users' attitudes may engender unforeseen repercussions for ICT diffusion in Syrian schools" (p. 374). It is safe to say that what Albirini described about Syria also holds true about Iran.

Obviously, several studies have been conducted to explore teachers' attitudes toward ICT integration in developed countries. However, there have been few studies examining this topic in developing countries, and even fewer concentrating on attitudes toward ICT among EFL teachers [4-8].

With the aforementioned points taken into account, the current study intended to contribute to the status quo of using technology in EFL classes in Iran and teachers' beliefs, attitudes, and actual use of different types of technology in their classes. To begin with, teachers' uses of technology, in particular, uses that enhance students' learning will not be increased, unless we take teachers' existing beliefs into consideration. In the second place, the review of the related literature failed to uncover a single study which had focused on public schools in Iran. Also, the studies carried out previously, which were very few, had studied almost exclusively the language institutes in Iran. In the third place, although a number of studies exist on Iranian EFL teachers' attitudes toward the use of computers in learning and teaching, there have been very few comprehensive studies conducted on Iranian public high school EFL teachers' attitudes toward the use of computers in learning and teaching, their perceived competence in integrating technology in classrooms, and the actual use of different types of technologies in classrooms in a single study, so the present study seemed significant since it aimed to contribute to the related literature in terms of the high school EFL teachers' attitudes toward TELL and their perceived competence in integrating technology in classrooms and the actual use of different types of technologies in classrooms. In the fourth place, the results of the present study will guide further research with regard to the aforementioned issues in the Iranian EFL teaching context. Last but definitely not least, the present study can be regarded as the first research at least in the Iranian context in which the three variables of teachers' attitudes, their perceived competence, and their actual use of different types of technology, in particular, the computer, were studied together. Also, the actual use of technology in the classroom was measured not by an observer who would sit in a teacher's class at most two sessions. Rather, it was decided by students at the end of the school year. Needless to say, such results can be much more reliable, and these last two points can be cited as the novel aspects which the present researchers have added to the available studies.

TELL lends itself to instruction based on the principles of constructivism and second language acquisition theories. As far as constructivism is concerned, the use of synchronous and asynchronous communication enables social interaction, which is vital to meaning construction. It is no wonder that TELL has been referred to as a vehicle for constructivist approaches in language classrooms [9]. From the perspective of the second language acquisition theory, social interaction using both communication modes enables EFL learners to experience comprehensible input [10] and negative evidence [11] and, at the same time, to experiment with their comprehensible output [12]. Accordingly, the use of the new technologies in the realm of EFL teaching and learning is grounded on and is innately compatible with, contemporary learning theories.

On the other hand, researchers from different fields have studied the process of adopting new innovations for more than 30 years, and one of the most popular adoption models is described by Rogers in his book, Diffusion of Innovations [13]. Also, Rogers' diffusion of innovations theory is the most appropriate for exploring the adoption of technology in higher education and educational environments [13]. Indeed, much diffusion research involves technological innovations, so Rogers usually used the word "technology" and "innovation" as synonyms. Rogers offered the following definition for an innovation: "An innovation is an idea, practice, or project that is perceived as new by an individual or other unit of adoption" (p. 12) [14].

In sum, people's attitude in general and EFL teachers' attitude in particular toward a new technology can be regarded a key element in its diffusion [14]. This proposition offered by Rogers confirms the general and widely accepted belief that attitudes affect behavior directly or indirectly [15].

Owing to the fact that this study explored the 3 research variables of attitudes, perceived competency, and actual use of technology together, the literature relating to each variable is reviewed separately, but to save space, the literature review is as brief and concise as possible.

Before reviewing the relevant literature, it should be pointed out that regarding teachers' attitudes toward technology in general, the literature abounds with studies in different countries and contexts [16-19], but the scarcity of discipline-based studies concerning EFL teachers' attitudes, particularly in developing countries, has been acknowledged by several researchers [20].

Nearly all studies investigating the attitudes of students (e.g., secondary mathematics and science students surveyed by [21]) and teachers (e.g., prospective EFL teachers surveyed by [22]; preservice ELT teachers in [23]; studentteachers in the study by [24]; teacher educators in [25]) at different grade levels(e.g., Turkish primary science teachers' attitudes studied by [26]; secondary mathematics and science teachers and 450 secondary students participating in the study by [21]) and across different subject matters (e.g., secondary mathematics and science teachers surveyed by [21]; teachers teaching in the science/mathematics, social sciences, literacy, physical education, and arts/music fields surveyed by [17]; technical and vocational teachers in Malaysia surveyed by [18]) have come to a similar conclusion: the participants surveyed commonly held a positive attitude toward technology. But the results of the study conducted by [21] showed 
that teachers' attitude toward technology uses in schools tended to be negative, while students' attitudes were summarized as enthusiastic.

When we turn to the field of teaching English as a second or a foreign language, we find studies and surveys having explored mainly the teachers' attitudes toward TELL $[4,5,7$, $8,20,27-32]$. Not surprisingly, positive attitude toward TELL has been the common conclusion in virtually all these studies.

Although the use of technology in education encompasses all school subject matters, and one expects many studies to have explored both the attitudes and perceived competence of those surveyed, finding a plethora of previous studies conducted on teachers' perceived competency in integrating technology in their classes did not prove to be as easy as $\mathrm{ABC}$.

Dashtestani [33] explored the perspectives of 39 Iranian EFL teacher trainers regarding possible challenges to EFL teachers' computer literacy development. According to this study, a significant challenge to teachers' improvement of their computer literacy was perceived to be the age differences and generation gap of EFL teachers.

In a mixed-methods study, Dashtestani [34] made an effort to uncover the perceptions of 263 Iranian EFL teachers on their computer literacy levels. He administered a computer literacy questionnaire and a general computer literacy test to the participants. Besides, he conducted follow-up indepth interviews with 24 EFL teachers who had also been present in the survey. The results of the study showed that the participants' levels of computer literacy were not adequate for the implementation of CALL, and the teachers used a limited range of computer applications. But, the EFL teachers adopted positive attitudes toward improving their computer literacy.

Studies conducted to explore teachers' perceived competency in integrating technology in education are relatively small in number. Besides, almost all studies carried out in Iran, which are very few in the case of EFL teachers, have been conducted in language institutes and, in some cases, at universities.

Gulbahar and Guven [35] conducted a study in Turkey to explore the use of ICT tools in primary schools in the social studies subject area. 326 teachers teaching fourth- and fifthgrade students at primary level completed a survey. The results indicated that though teachers were keen to use ICT resources and were cognizant of the existing potential, they faced problems regarding the accessibility of ICT resources and lack of in-service training opportunities.

Afshari et al. [31] conducted a study to identify the extent to which Iranian secondary school principals used computers and to explore the relationship between a number of variables related to the use of information and communications technology (ICT). Their findings indicated that four factors played a role in explaining the level of computer use by principals. These four factors, that is, high level of computer access, strong perceptions of the attributes of ICT, high level of computer competence, and high level of transformational leadership behaviors, all contributed significantly to the level of computer use by principals.
TABLE 1: The in-service EFL teachers in five school districts during the school year 2015-2016.

\begin{tabular}{|c|c|c|c|c|}
\hline \multirow{3}{*}{ School district } & \multicolumn{4}{|c|}{ Grade level } \\
\hline & \multicolumn{2}{|c|}{ Junior } & \multicolumn{2}{|c|}{ Senior } \\
\hline & Male & Female & Male & Female \\
\hline 1 & $11(2.7 \%)$ & $26(6.59 \%)$ & $15(3.80 \%)$ & $20(5.07 \%)$ \\
\hline 2 & $13(3.2 \%)$ & $19(4.82 \%)$ & $25(6.34 \%)$ & $18(4.56 \%)$ \\
\hline 3 & $20(5.07 \%)$ & $36(9.13 \%)$ & $13(3.2 \%)$ & $29(7.36 \%)$ \\
\hline 4 & $11(2.7 \%)$ & 27 (6.85\%) & $22(5.58 \%)$ & $24(6.09 \%)$ \\
\hline 5 & $18(4.56 \%)$ & $22(5.58 \%)$ & $10(2.53 \%)$ & $15(3.80 \%)$ \\
\hline
\end{tabular}

To bridge the gaps in the related literature, the present researchers posed the following research questions:

Q1: Do Iranian EFL teachers at high schools have an overall positive or negative attitude toward integrating educational technology into their classrooms?

Q2: Do Iranian EFL teachers at high schools have an overall high or low perceived competency in integrating educational technology into their classrooms?

Q3: Do Iranian EFL teachers at high schools make an overall high or low use of educational technology in their classrooms?

\section{Methodology}

2.1. Participants. To provide the research questions of the present study with appropriate answers, two groups of participants were needed.

The first group of participants was needed to answer RQs 1 and 2. These participants were seventh- to twelfth-grade high school EFL male and female teachers in Tabriz, Iran. Their teaching experience ranged from 5 years to 30 years. They had AA, BA, and MA degrees in fields related to English, such as EFL, English literature, and English translation. Their age ranged from 30 to 66 years. Also, it should be added that Tabriz has 5 educational districts, and this study included the teachers in all districts.

Making an allowance for the often quoted "the larger, the better" principle regarding sample size, but at the same time, taking the proportion of teachers at various school districts and also the number of male and female teachers at different grade levels, the researchers adopted stratified cluster sampling method to choose at least 30\% (this figure was the recommendation of a reliable statistician) of the population as the representative sample for the present study.

As Table 1 makes it clear, our population for this study comprised $394 \mathrm{EFL}$ teachers, and we decided to choose $30 \%$ (i.e., $120 \mathrm{EFL}$ teachers) of this population as the representative sample for our research. But a closer look at Table 1 uncovers some important facts which could not be taken a blind eye at. For instance, school district 3 had the most teachers of all districts (98 teachers or 24.87 percent or roughly one quarter of the population of teachers). Having 84 teachers, district 4 was placed in the second position in this respect. On the other hand, districts 1 and 2 had approximately the same number of teachers (i.e., 72 and 75 
teachers, resp.). Finally, district 5 had the least number of teachers, that is, 65 . Also, regarding the number of male and female teachers, we noticed that 158 male teachers (40\%) and $236(60 \%)$ female teachers were present in our population. So in order to have a representative sample which took into account the above-mentioned two points, we opted for stratified cluster sampling, the result of which is presented in Table 2.

The second group of participants was needed so as to answer RQ3. The population in question comprised all male and female students aged between 14 and 19 years old and studying in junior and senior high schools of Tabriz.

The procedure for choosing the representative sample of students for this research was not so straightforward. Bearing in mind the point that a representative sample of these students was needed to explore their respective teachers' use of technology in classrooms, their selection was not completely random. The researchers had already chosen the required and specific teachers for the study at random, and at this point, those students would be selected who had attended the already-chosen English teachers' classes during the previous school year. Of course, not all students were needed to fill out the questionnaire for a specific teacher. In this regard, the researchers decided that 5 questionnaires (the number recommended by a statistician) would be sufficient for every teacher. In other words, at least 5 students evaluated a specific teacher's use of educational technology in their classes.

2.2. Research Design. This was a descriptive and quantitative-qualitative study utilizing a cross-sectional survey design, which implies that the researchers gathered data at one point in time with an interest in describing relationships among variables [36]. Furthermore, this study was largely exploratory in nature. Few comprehensive or somehow exhaustive researches have been conducted by researchers on the use of technology by high school English teachers in Asia in general and in Iran in particular.

2.3. Instrumentation. To find answers for the research questions of the present study, two instruments were utilized. To answer RQs 1 and 2, the instrument was a modified and adapted version of an already available questionnaire (The Survey of High School EFL Teachers' Attitudes toward Computer Technology) developed by [4].

For the present study, the questionnaire comprised three sections. The first section aimed at collecting some personal and demographic information like gender, age, number of years of teaching experience, academic degree (AA, BA, MA, $\mathrm{PhD}$ ), type of teaching school, and grade level taught (junior/senior high school) from the participants (EFL teachers). The second section dealt with the attitudes of the Iranian high school English teachers toward computers and other technologies accessible in Iranian classrooms nowadays. This section included 30 statements. The first 20 items were copied with minor changes from [4], but items 21-30 were adapted from [32]. Each of these items utilized a fivepoint Likert-type scale ( $1=$ strongly disagree, $2=$ disagree,
TABLE 2: The proportion of teachers in the randomly selected sample in which stratification variables were related to gender and the school district.

\begin{tabular}{lcccc}
\hline \multirow{2}{*}{ School district } & \multicolumn{3}{c}{ Junior } & \multicolumn{2}{c}{ Senior } \\
& Male & Female & Male & Female \\
\hline 1 & $4(3.33 \%)$ & $7(5.83 \%)$ & $5(4.16 \%)$ & $6(5 \%)$ \\
2 & $4(3.33 \%)$ & $6(5 \%)$ & $8(6.66 \%)$ & $5(4.16 \%)$ \\
3 & $6(5 \%)$ & $10(8.33 \%)$ & $4(3.33 \%)$ & $9(7.5 \%)$ \\
4 & $3(2.5 \%)$ & $8(6.66 \%)$ & $7(5.83 \%)$ & $8(6.66 \%)$ \\
5 & $6(5 \%)$ & $6(5 \%)$ & $4(3.33 \%)$ & $4(3.33 \%)$ \\
\hline
\end{tabular}

$3=$ neutral, $4=$ agree, and $5=$ strongly agree). The third section of the questionnaire dealt with the perceived computer competency of the participants. This section was also copied from [4], of course with minor changes. It included 15 four-point likert-type items.

As it was mentioned earlier, some modifications were inevitable in the original questionnaire used by [4]. For this reason, a pilot study was run not only for the first instrument (The Survey of High School EFL Teachers' Attitudes toward Computer Technology) but also in the case of the second questionnaire (Student Questionnaire Surveying the Use of Educational Technology by English Teachers in Classrooms).

To answer RQ3, another instrument was used. This instrument was a questionnaire, too, but it was designed for the students studying at junior and senior high schools in Tabriz. It had two sections. The first section asked some personal information, like gender, grade level, educational (school) district, and type of school (public or private, etc.). The second section included 14 six-point likert-type items ( $1=$ never, $2=$ rarely, $3=$ sometimes, $4=$ usually, $5=$ often, and $6=$ always). The students indicated the frequency with which their English teachers had used different educational technologies (blackboards/whiteboards, the Internet, CDROMs, PowerPoint slides, electronic dictionaries, projectors, smart phones, laptops, tablets, educational websites, etc.) inside or outside the classroom during the school year. To design and prepare this questionnaire, the researchers had done as much relevant literature review as they had been able to and had also consulted with several educational technology experts and EFL teachers. However, its validity and reliability needed to be ascertained. It should be added that the students' questionnaire was administered in Farsi, so the validity and reliability of the Farsi version of this questionnaire needed to be ascertained.

2.4. Procedure. To ascertain the reliability of the first questionnaire, a modified version of an already accessible one (Albirini's The Survey of High School EFL Teachers' Attitudes toward Computer Technology) for the present study, a pilot survey was conducted. In this pilot study, 30 high school English teachers answered the items comprising the teachers' questionnaire, and the results were used to calculate the reliability of the questionnaire. The Cronbach's $\alpha$ reliability coefficients for the two scales in 
TABLe 3: Questionnaire results for EFL teachers' attitudes toward the integration of educational technology in their classes.

\begin{tabular}{|c|c|c|c|c|c|c|c|}
\hline Items & $\mathrm{SD} \%$ & $\mathrm{D} \%$ & $\mathrm{~N} \%$ & $\mathrm{~A} \%$ & SA\% & Mean & Standard deviation \\
\hline (1) Computers do not scare me at all. & 2.7 & 14.3 & 20.5 & 33.0 & 29.5 & 3.72 & 1.11 \\
\hline (2) Computers make me feel uncomfortable*. & 0.9 & 5.4 & 16.1 & 42.0 & 37.5 & 4.06 & 0.90 \\
\hline $\begin{array}{l}\text { (3) I do not like talking with others about } \\
\text { computers*. }\end{array}$ & 2.7 & 6.2 & 13.4 & 44.6 & 33.0 & 3.99 & 0.98 \\
\hline (4) I am glad there are more computers these days. & 2.7 & 5.4 & 11.6 & 40.2 & 40.2 & 4.10 & 0.98 \\
\hline (5) Using computers is enjoyable. & 0.9 & 7.1 & 10.7 & 46.4 & 34.8 & 4.07 & 0.90 \\
\hline (6) I dislike using computers in teaching*. & 1.8 & 2.7 & 8.0 & 46.4 & 41.1 & 4.22 & 0.84 \\
\hline (7) Computers save time and effort. & 3.6 & 6.2 & 14.3 & 44.6 & 31.2 & 3.94 & 1.01 \\
\hline $\begin{array}{l}\text { (8) Schools would be a better place without } \\
\text { computers*. }\end{array}$ & 5.4 & 2.7 & 8.0 & 40.2 & 43.8 & 4.14 & 1.04 \\
\hline (9) Learning about computers is a waste of time*. & 0.9 & 2.7 & 4.5 & 39.3 & 52.7 & 4.40 & 0.77 \\
\hline $\begin{array}{l}\text { (10) Students must use computers in all subject } \\
\text { matters. }\end{array}$ & 1.8 & 15.2 & 17.0 & 45.5 & 20.5 & 3.68 & 1.02 \\
\hline $\begin{array}{l}\text { (11) Computers would motivate students to do more } \\
\text { study. }\end{array}$ & 0.9 & 8.9 & 13.4 & 57.1 & 19.6 & 3.86 & 0.86 \\
\hline $\begin{array}{l}\text { (12) Computers are a fast and efficient means of } \\
\text { getting information. }\end{array}$ & 0.0 & 3.6 & 4.5 & 58.0 & 33.9 & 4.22 & 0.69 \\
\hline $\begin{array}{l}\text { (13) I think I will never need a computer in my } \\
\text { classroom*. }\end{array}$ & 1.8 & 3.6 & 8.0 & 46.6 & 40.2 & 4.20 & 0.86 \\
\hline (14) Computers can enhance students' learning. & 0.0 & 2.7 & 18.8 & 53.6 & 25.0 & 4.01 & 0.74 \\
\hline (15) Computers do more harm than good*. & 0.9 & 11.6 & 23.2 & 48.2 & 16.1 & 3.6 & 0.91 \\
\hline $\begin{array}{l}\text { (16) I would rather do things by hand than with } \\
\text { a computer*. }\end{array}$ & 2.7 & 12.5 & 18.8 & 50.9 & 15.2 & 3.63 & 0.97 \\
\hline $\begin{array}{l}\text { (17) If I had the money, I would buy a computer or } \\
\text { a laptop. }\end{array}$ & 1.8 & 1.8 & 8.9 & 54.5 & 33.0 & 4.15 & 0.79 \\
\hline (18) I would avoid computers as much as possible*. & 0.9 & 5.4 & 13.4 & 47.3 & 33.0 & 4.06 & 0.87 \\
\hline (19) I would like to learn more about computers. & 1.8 & 3.6 & 8.9 & 51.8 & 33.9 & 4.12 & 0.85 \\
\hline $\begin{array}{l}\text { (20) I have no intention to use computers in the near } \\
\text { future*. }\end{array}$ & 2.7 & 2.7 & 14.3 & 50.9 & 29.5 & 4.02 & 0.89 \\
\hline $\begin{array}{l}\text { (21) Computer technologies provide nonnative } \\
\text { speakers of English with rich learning environment. } \\
\text { They can practice the activities as many times as they } \\
\text { wish. }\end{array}$ & 1.8 & 11.6 & 20.5 & 43.8 & 22.3 & 3.73 & 0.99 \\
\hline $\begin{array}{l}\text { (22) Technology plays a great role in learning the } \\
\text { different language skills. }\end{array}$ & 0.0 & 4.5 & 13.4 & 50.0 & 32.1 & 4.10 & 0.79 \\
\hline $\begin{array}{l}\text { (23) Using technology in the classroom has many } \\
\text { benefits to teachers and students alike. }\end{array}$ & 0.0 & 3.6 & 9.8 & 52.7 & 33.9 & 4.17 & 0.74 \\
\hline $\begin{array}{l}\text { (24) Students can interact and communicate } \\
\text { differently with the help of educational technology. }\end{array}$ & 0.9 & 3.6 & 16.1 & 53.6 & 25.9 & 4.00 & 0.80 \\
\hline $\begin{array}{l}\text { (25) Educational technology assists students in } \\
\text { improving their academic achievement and grades. }\end{array}$ & 1.8 & 3.6 & 16.1 & 57.1 & 21.4 & 3.93 & 0.82 \\
\hline $\begin{array}{l}\text { (26) Educational technology assists in making } \\
\text { language learning interesting and enjoyable. }\end{array}$ & 0.9 & 4.5 & 12.5 & 44.6 & 37.5 & 4.13 & 0.86 \\
\hline $\begin{array}{l}\text { (27) Educational technology helps in integrating } \\
\text { different language activities. }\end{array}$ & 0.0 & 2.7 & 18.8 & 56.2 & 22.3 & 3.98 & 0.72 \\
\hline $\begin{array}{l}\text { (28) Educational technology assists in putting } \\
\text { traditional approaches aside and developing more } \\
\text { interactive ways in teaching and learning languages. }\end{array}$ & 1.8 & 3.6 & 20.5 & 57.1 & 17.0 & 3.84 & 0.81 \\
\hline $\begin{array}{l}\text { (29) Educational technology plays no role in learning } \\
\text { different language skills*. }\end{array}$ & 3.6 & 8.0 & 10.7 & 47.3 & 30.4 & 3.93 & 1.02 \\
\hline $\begin{array}{l}\text { (30) Students become more dependent learners as } \\
\text { a result of educational technology*. }\end{array}$ & 6.2 & 28.6 & 27.7 & 30.4 & 7.1 & 3.04 & 1.06 \\
\hline Overall attitude & 1.79 & 6.62 & 14.08 & 47.79 & 29.78 & 3.94 & 0.88 \\
\hline
\end{tabular}

$\mathrm{SD}=$ strongly disagree, $\mathrm{D}=$ disagree, $\mathrm{N}=$ neutral, $\mathrm{A}=$ agree, $\mathrm{SA}=$ strongly agree. Items marked by an asterisk were reversed ones. 
TABLE 4: Questionnaire results for EFL teachers' perceived competency in integrating educational technology in their classes.

\begin{tabular}{|c|c|c|c|c|c|c|}
\hline Items & No com.\% & Little com.\% & Moderate com.\% & Much com. $\%$ & Mean & $\mathrm{SD}$ \\
\hline (1) Installing new software on a computer & 19.6 & 20.5 & 41.1 & 18.8 & 2.59 & 1.00 \\
\hline (2) Using a printer & 5.4 & 21.4 & 37.5 & 35.5 & 3.04 & 0.89 \\
\hline (3) Using a computer keyboard & 2.7 & 12.5 & 43.8 & 41.1 & 3.23 & 0.77 \\
\hline (4) Operating a word processing program (e.g., Word) & 2.7 & 20.5 & 38.4 & 38.4 & 3.12 & 0.82 \\
\hline $\begin{array}{l}\text { (5) Operating a presentation program (e.g., } \\
\text { PowerPoint) }\end{array}$ & 9.8 & 28.6 & 38.4 & 23.2 & 2.75 & 0.92 \\
\hline (6) Operating a spreadsheet program (e.g., Excel) & 36.6 & 28.6 & 25.9 & 8.9 & 2.07 & 0.99 \\
\hline (7) Operating a database program (e.g., Access) & 35.7 & 30.4 & 25 & 8.9 & 2.07 & 0.98 \\
\hline $\begin{array}{l}\text { (8) Using the Internet for communication (e.g., } \\
\text { e-mail \& chatroom) }\end{array}$ & 11.6 & 21.4 & 28.6 & 38.4 & 2.94 & 1.03 \\
\hline $\begin{array}{l}\text { (9) Using the World Wide Web to access different } \\
\text { types of information }\end{array}$ & 5.4 & 21.4 & 38.4 & 34.8 & 3.03 & 0.88 \\
\hline (10) Solving simple problems in operating computers & 15.2 & 29.5 & 42 & 13.4 & 2.54 & 0.91 \\
\hline (11) Operating a graphics program (e.g., Photoshop) & 43.8 & 28.6 & 25.9 & 1.8 & 1.86 & 0.86 \\
\hline (12) Using computers for grade keeping & 22.3 & 26.8 & 38.4 & 12.5 & 2.41 & 0.97 \\
\hline (13) Selecting and evaluating educational software & 16.1 & 34.8 & 40.2 & 8.9 & 2.42 & 0.88 \\
\hline (14) Creating and organizing computer files and folders & 15.2 & 20.5 & 40.2 & 24.1 & 2.73 & 0.99 \\
\hline (15) Removing computer viruses & 29.5 & 28.6 & 28.6 & 13.4 & 2.26 & 1.02 \\
\hline Overall competence & 18.10 & 24.94 & 35.49 & 21.47 & 2.60 & 0.92 \\
\hline
\end{tabular}

the questionnaire were: computer attitude $=0.88$ and perceived computer competence $=0.95$.

After ascertaining that this instrument was sufficiently reliable, the main survey was started. Fortunately, the first author of this paper had somehow easy access to the participants (teachers) since he is a high school teacher himself. In addition, both junior and senior high school teachers attended at least two workshops during the school year. These workshops provided the best opportunity for distributing questionnaires, answering participants' possible questions while they were filling them out and finally getting them back.

A pilot study was conducted to ascertain the reliability of the students' questionnaire, too. Fifty high school students participated in the pilot study whose purpose was to calculate the reliability of the instrument. The original questionnaire comprised 15 items, but the results of the pilot study indicated that one item had a negative effect on the reliability of the questionnaire, so that item was excluded and the number of items was decreased to 14 . The Cronbach's $\alpha$ reliability coefficient for the students' questionnaire was 0.73 which was acceptable.

Having done this, the researchers obtained the required permits from the education office of all five school districts to be surveyed to give the questionnaire personally to students at their respective schools and ask them to kindly fill out the questionnaire. The students were convinced that the questionnaire had been designed solely for research purposes and would have no impact on their school performance or grades. Also, they were completely free to fill out the questionnaire or not.

It should also be reminded that the questionnaires were answered during the summer holidays between two school years. This point can also be regarded as another factor increasing the reliability of the findings, since during summer, students do not see their previous (last school year's) English teacher and have no contact with him/her, and their answers can be more reliable and without being influenced by factors which would be unavoidable and influential if the questionnaires were distributed during the school year.

When the required data were collected via questionnaires, they were analysed by using SPSS version 16. Descriptive statistics (frequencies, means, percentages, and standard deviations) were used in the analysis, and the results are presented in the following section. The data were double checked to guarantee accuracy.

\section{Findings and Discussion}

Research question one asked whether Iranian EFL teachers at high schools had an overall positive or negative attitude toward integrating technology into their classrooms. Questionnaire results for EFL teachers' attitudes toward the integration of educational technology in their classes are presented in Table 3.

As Table 3 shows, Iranian high school EFL teachers' attitudes toward TELL were positive, with an overall mean of 3.94 and a standard deviation of 0.88 . High school EFL teachers' positive attitudes toward TELL indicated their initiation into the innovation decision process [14]. Hence, it can be argued that Iranian high school EFL teachers have already passed the Knowledge and Persuasion stages [14] and are most likely advancing to the Decision phase.

The second research question asked whether Iranian EFL teachers at high schools had an overall high or low perceived 
TABLE 5: Questionnaire results for EFL teachers' actual use of educational technology in their classes.

\begin{tabular}{|c|c|c|c|c|c|c|c|c|}
\hline Items & Never\% & Rarely\% & Sometimes\% & Usually\% & Often $\%$ & Always\% & Mean & $\mathrm{SD}$ \\
\hline $\begin{array}{l}\text { (1) My English teacher uses an electronic dictionary in } \\
\text { the class when (s) he needs to look up a word. }\end{array}$ & 39.7 & 24.4 & 18.2 & 4.9 & 7.3 & 5.5 & 2.32 & 1.486 \\
\hline $\begin{array}{l}\text { (2) I know my English teacher's e-mail address, and I } \\
\text { can ask my questions from him/her by sending an } \\
\text { e-mail to him/her. }\end{array}$ & 85.5 & 5.1 & 3.0 & 2.8 & 2.1 & 1.5 & 1.35 & 1.004 \\
\hline $\begin{array}{l}\text { (3) My English teacher uses the blackboard/whiteboard } \\
\text { in the teaching-learning process. }\end{array}$ & 2.1 & 4.1 & 7.5 & 12.6 & 16.9 & 56.8 & 5.08 & 1.301 \\
\hline $\begin{array}{l}\text { (4) My English teacher uses educational CDs in the } \\
\text { classroom. }\end{array}$ & 42.1 & 10.3 & 8.6 & 5.8 & 10.9 & 22.2 & 3.00 & 2.07 \\
\hline $\begin{array}{l}\text { (5) My English teacher uses PowerPoint slides to } \\
\text { teach grammar. }\end{array}$ & 42.5 & 14.5 & 13.7 & 9.0 & 13.0 & 7.3 & 2.58 & 1.714 \\
\hline $\begin{array}{l}\text { (6) My English teacher uses typed test papers, not } \\
\text { handwritten ones. }\end{array}$ & 3.9 & 4.7 & 6.0 & 8.6 & 14.7 & 62.0 & 5.11 & 1.412 \\
\hline $\begin{array}{l}\text { (7) My English teacher uses educational films in the } \\
\text { classroom. }\end{array}$ & 50.2 & 12.0 & 10.5 & 9.4 & 8.8 & 9.0 & 2.42 & 1.747 \\
\hline $\begin{array}{l}\text { (8) My English teacher introduces Internet sites } \\
\text { which are useful for learning English. }\end{array}$ & 56.8 & 19.7 & 9.8 & 6.4 & 4.5 & 2.8 & 1.91 & 1.331 \\
\hline $\begin{array}{l}\text { (9) My English teacher asks students to make } \\
\text { PowerPoint slides. }\end{array}$ & 38.5 & 14.3 & 13.0 & 9.2 & 13.2 & 11.8 & 2.80 & 1.826 \\
\hline $\begin{array}{l}\text { (10) My English teacher encourages students to listen } \\
\text { to English educational CDs at home. }\end{array}$ & 32.3 & 17.9 & 9.8 & 10.7 & 12.2 & 17.1 & 3.04 & 1.901 \\
\hline $\begin{array}{l}\text { (11) My English teacher encourages students to watch } \\
\text { English educational films at home. }\end{array}$ & 38.2 & 18.5 & 11.5 & 10.5 & 10.7 & 10.3 & 2.68 & 1.755 \\
\hline $\begin{array}{l}\text { (12) My English teacher encourages pupils to search } \\
\text { for information on the Internet. }\end{array}$ & 38.9 & 24.4 & 14.1 & 10.3 & 7.3 & 4.9 & 2.37 & 1.500 \\
\hline $\begin{array}{l}\text { (13) We send our homework assignments to our } \\
\text { English teacher by e-mail. }\end{array}$ & 92.9 & 3.8 & 1.3 & 1.1 & 0.9 & 0.0 & 1.14 & 0.570 \\
\hline $\begin{array}{l}\text { (14) My English teacher uses the computer or his/her } \\
\text { own laptop or tablet as a grade book. }\end{array}$ & 87.2 & 6.0 & 3.6 & 1.3 & 0.8 & 1.1 & 1.26 & 0.812 \\
\hline EFL teachers' overall actual technology use & 46.5 & 12.8 & 9.32 & 7.32 & 8.80 & 15.1 & 2.64 & 1.459 \\
\hline
\end{tabular}

competency in integrating educational technology into their classrooms. Respecting this question, the questionnaire results for EFL teachers' perceived competency in integrating educational technology in their classes are presented in Table 4.

In accordance with Table 4, Iranian high school EFL teachers' competency in integrating educational technology in their teaching is not satisfactorily high, with an overall mean of 2.60 and a standard deviation of 0.92 . In other words, the teachers are not sufficiently competent to make use of technology in their classes.

The third research question asked whether Iranian EFL teachers at high schools made an overall high or low use of educational technology in their classrooms. Concerning this question, the questionnaire results for EFL teachers' actual use of technology in their classes are presented in Table 5.

As Table 5 illustrates, the total mean of the questionnaire is equal to 2.64 which shows that Iranian EFL teachers at high schools make an overall very low use of educational technology in their classrooms. In other words, according to the results presented in the table, technology does not enjoy a good place in Iranian EFL classes and is largely overlooked by EFL teachers.
To set the record straight, Iranian high school EFL teachers do not adopt technology enhanced language learning as a primary mode of instruction. Rather, technology is used occasionally as a supplement to traditional face-to-face classroom instruction [37]. Even using PowerPoint slides to present a lesson and asking students to search the Web for information resources which are examples of "low-level" uses of technology, that is, those that support traditional, teacher-directed instruction [38], is not a common practice in high school English classes. Becker [39] believes that teachers having traditional pedagogical beliefs will continue to make use of computers to support traditional skill- and fact-oriented instructions, but even this does not happen in Iranian high school EFL classes as much and frequently as it is desirable and expected.

\section{Conclusion}

This study explored Iranian high school EFL teachers' attitudes toward, their perceived competency in, and their actual use of educational technology in their classrooms. The results indicated that even though Iranian teachers have an overall positive attitude toward educational technology, they 
are not sufficiently competent to use it in their classes, and this lack of competence may be one of the main barriers to the full use of technology in their classes. In addition, educational technology, unfortunately, does not enjoy a decent place in Iranian high school English classes.

A number of steps can be taken in order to help Iranian high school English teachers develop their technologyrelated skills. First, they should be convinced that educational technology facilitates their routine jobs regarding their occupation. Unluckily, many teachers, even those who are competent enough to utilize technology, seemingly have a negative mindset respecting educational technology. The educational decision and policy makers are required to think of strategies and plans to make teachers aware of huge benefits they can reap if they avail themselves of educational technology as much as possible.

Second, education and instruction is test-oriented in Iran. Those English teachers are regarded successful in their jobs whose students score the passing grade and get the highest marks in external exams such as the national university entrance examination. For this reason, on the one hand, teachers are inclined to teach what they suppose will be posed in the exam. On the other hand, they aim at teaching their students a number of so-called shortcuts to answer examination questions, so learning is limited to getting the passing grade in tests. Needless to say, educational technology is taken a blind eye on in such classes. To solve this problem, learner-centered teaching approaches should replace the traditional teacher-centered approaches, and if a fundamental change is going to take place in Iranian national education, exam-oriented teaching must be put aside. Top policy makers are called in to pave the way for the adoption of learner-centered approaches and help the teachers create the contexts with ample opportunities for the effective use of learner-centered approaches fostering learners' creativity and innovation.

Third, it is recommended that the decision makers in the Iranian Ministry of Education encourage teachers to enhance their computer- and technology-related skills in order to be able to integrate technology in their classes. Although teachers have attended several in-service classes in the past years, such classes have not been taken seriously, and they have not been very useful or helpful for the teachers. The officials in question need to offer and implement strategies aimed at taking the most advantage of classes mentioned above. Also, such classes will be beneficial if teachers themselves are enthusiastic to participate in those classes.

Fourth, teaching is not financially rewarding in Iran. Sad to say, the majority of Iranian teachers do not earn enough money in their jobs to support their families. Many teachers have to find another job and perhaps other jobs beside their regular one in order to make a living. It goes without saying that such teachers will not have the money, time, and above all the motivation to keep abreast of the latest developments in teaching and educational technology. Again, solving this problem lies in the hands of top policy makers in the education ministry.

Last, but definitely not least, if technology is to be used as a tool to support the educational objectives like skills for searching and assessing information, cooperation, communication, and problem solving which are vital for the preparation of students for the knowledge society [40], and since it is believed that innovative use of ICT can facilitate student centered learning [40], studies need to be conducted in the Iranian context to pinpoint other barriers which hinder the full integration of technology in EFL classes.

\section{Conflicts of Interest}

The authors declare that there are no conflicts of interest regarding the publication of this paper.

\section{References}

[1] U. Stickler and L. Shi, "TELL us about CALL: an introduction to the Virtual Special Issue (VSI) on the development of technology enhanced and computer assisted language learning published in the System Journal," System, vol. 56, pp. 119-126, 2016.

[2] C. Blurton, "New directions of ICT: use in education," UNESCO Report, 2002. http://www.unesco.org/education/lwf/dl/edict.pdf, Retrieved October 29, 2015.

[3] L. Cheng and A. Curtis, Washback or Backwash: A Review of the Impact of Testing on Teaching and Learning, Lawrence Erlbaum Associates, Inc., Publishers, Mahwah, NJ, USA, 2008.

[4] A. Albirini, "Teachers' attitudes toward information and communication technologies: the case of Syrian EFL teachers," Computers and Education, vol. 47, no. 4, pp. 373398, 2006.

[5] Z. T. Abu Samak, "An exploration of Jordanian English language teachers' attitudes, skills, and access as indicator of information and communication technology (ICT) integration in Jordan," Electronic Theses, Treatises and Dissertations, Paper 106, 2006.

[6] B. T. Lau and C. H. Sim, "Exploring the extent of ICT adoption among Secondary school teachers in Malaysia," International Journal of Computing and ICT Research, vol. 2, no. 2, pp. 19-36, 2008.

[7] A. Sahin-Kizil, "EFL teachers' attitudes towards Information and Communication Technologies (ICT)," in Proceedings of the 5th International Computer \& Instructional Technologies Symposium, Firat University, Elaziğ, Turkey, September 2011.

[8] S. Aydin, "Teachers' perceptions about the use of computers in EFL teaching and learning: the case of Turkey," Computer Assisted Language Learning, vol. 26, no. 3, pp. 214-233, 2013.

[9] U. Felix, "The web as a vehicle for constructivist approaches in language teaching," ReCALL, vol. 14, no. 1, pp. 2-15, 2002.

[10] S. D. Krashen, The Input Hypothesis: Issues and Implications, Longman, London, UK, 1985.

[11] M. H. Long, "The role of the linguistics environment in second language acquisition," in Handbook of Second Language Acquisition, W. Ritchie and T. Bahtia, Eds., pp. 413-468, Academic Press, San Diego, CA, USA, 1996.

[12] M. Swain, "Three functions of output in second language learning," in Principles and Practices in Applied Linguistics: Studies in Honor of H. G. Widdowson, G. Cook and G. Seidlhofer, Eds., pp. 125-144, Oxford University Press, Oxford, UK, 1995.

[13] I. Sahin, "Detailed review of Rogers' diffusion of innovations theory and educational technology-related studies based on Rogers' theory," TOJET-Turkish Online Journal of Educational Technology, vol. 5, no. 2, pp. 14-23, 2006. 
[14] E. M. Rogers, Diffusion of Innovations, Free Press, New York, NY, USA, 5th edition, 2003.

[15] A. Albirini, "An exploration of the factors associated with the attitudes of high school EFL teachers in Syria toward information and communication technology," Unpublished doctoral dissertation, The Ohio State University, Columbus, OH, USA, 2004.

[16] J. Bauer and J. Kenton, "Toward technology integration in the schools: why it isn't happening," Journal of Technology and Teacher Education, vol. 13, no. 4, pp. 519-546, 2005.

[17] A. Kahveci, N. Şahin, and Ş. Genc, "Computer perceptions of secondary school teachers and impacting demographics: a Turkish perspective," TOJET-Turkish Online Journal of Educational Technology, vol. 10, no. 1, pp. 71-80, 2011.

[18] A.-O. Alazzam, A. R. Bakar, R. Hamzah, and S. Asimiran, "Effects of demographic characteristics, educational background, and supporting factors on ICT readiness of technical and vocational teachers in Malaysia," International Education Studies, vol. 5, no. 6, pp. 229-243, 2012.

[19] F. Ghaemi and M. Mostafavi, "The status of computer-assisted language learning in Iran," International Journal of Educational Investigations, vol. 2, no. 2, pp. 121-127, 2015.

[20] Y. A. Alshumaimeri, "Perceptions and attitudes toward using CALL in English classrooms among Saudi secondary EFL teachers," JALT CALL Journal, vol. 4, no. 2, pp. 29-46, 2008.

[21] Q. Li, "Student and teacher views about technology: a tale of two cities?," Journal of Research on Technology in Education, vol. 39, no. 4, pp. 377-397, 2007.

[22] M. Hismanoglu, "Prospective EFL teachers' perceptions of ICT integration: a study of distance higher education in Turkey," Educational Technology \& Society, vol. 15, no. 1, pp. 185-196, 2012.

[23] A. Sarıçoban, "Pre-service ELT teachers' attitudes towards computer use: a Turkish survey," Egitim Arastirmalari-Eurasian Journal of Educational Research, vol. 53, pp. 59-78, 2013.

[24] M. O. Yusuf and M. R. Balogun, "Student-teachers' competence and attitude towards Information and Communication Technology: a case study in a Nigerian University," Contemporary Educational Technology, vol. 2, no. 1, pp. 18-36, 2011.

[25] R. Nishta, "A study to assess teacher educators' attitudes towards technology integration in classrooms," MIER Journal of Educational Studies, Trends \& Practices, vol. 2, no. 2, pp. 190-205, 2012.

[26] B. Cavas, P. Cavas, B. Karaoglan, and T. Kisla, "A study on science teachers' attitude toward information and communication technologies in education," TOJET-Turkish Online Journal of Educational Technology, vol. 8, no. 2, pp. 20-32, 2009.

[27] C. N. Park and J. B. Son, "Implementing computer-assisted language learning in the EFL classroom: teachers' perceptions and perspectives," International Journal of Pedagogies \& Learning, vol. 5, no. 2, pp. 80-101, 2009.

[28] R. Dashtestani, "Barriers to the implementation of CALL in EFL courses:Iranian EFL teachers' attitudes and perspectives," JALT CALL Journal, vol. 8, no. 2, pp. 55-70, 2012.

[29] S. Bolandifar, N. Noordin, P. Babashamsi, and N. Shakib, "Teachers' attitudes toward integrating Internet technology in English classes," International Journal of Language Learning and Applied Linguistics World, vol. 4, no. 3, pp. 81-93, 2013.

[30] D. Tafazoli and N. S. Golshan, "Technology-enhanced language learning tools in Iranian EFL context: frequencies, attitudes and challenges," Global Journal of Information Technology, vol. 4, no. 1, pp. 7-12, 2014.
[31] M. Afshari, K. Abu Bakar, W. Su Luan, M. Afshari, F. Say Fooi, and B. A. Samah, "Computer use by secondary school principals," TOJET-Turkish Online Journal of Educational Technology, vol. 9, no. 3, pp. 8-25, 2010.

[32] F. Mollaei and M. Riasati, "Teachers' perceptions of using technology in teaching EFL," International Journal of Applied Linguistics \& English Literature, vol. 2, no. 1, pp. 13-22, 2013.

[33] R. Dashtestani, "Exploring English as a foreign language (EFL) teacher trainers' perspectives on challenges to promoting computer literacy of EFL teachers," JALT CALL Journal, vol. 10, no. 2, pp. 139-151, 2014.

[34] R. Dashtestani, "Computer literacy of Iranian teachers of English as a foreign language: challenges and obstacles," International Journal of Pedagogies and Learning, vol. 9, no. 1, pp. 87-100, 2014.

[35] Y. Gulbahar and I. Guven, "A survey on ICT usage and the perceptions of social studies teachers in Turkey," Educational Technology \& Society, vol. 11, no. 3, pp. 37-51, 2008.

[36] R. Tate, An Introduction to Modeling Outcomes in the Behavioral and Social Sciences, Burgess International Group, Edina, MN, USA, 2nd edition, 1998.

[37] A. Alberth, "Technology-enhanced teaching: a revolutionary approach to teaching English as a foreign language," TEFLIN Journal, vol. 24, no. 1, pp. 1-13, 2013.

[38] P. A. Ertmer and A. T. Ottenbreit-Leftwich, "Teacher technology change: how knowledge, confidence, beliefs, and culture intersect," Journal of Research on Technology in Education, vol. 42, no. 3, pp. 255-284, 2010.

[39] C. P. Lim and C. S. Chai, “Teachers' pedagogical beliefs and their planning and conduct of computer mediated classroom lessons," British Journal of Educational Technology, vol. 39, no. 5, pp. 804-828, 2008.

[40] M. Afshari, K. Abu Bakar, W. Su Luan, B. Abu Samah, and F. Say Fooi, "Factors affecting teachers' use of information and communication technology," International Journal of Instruction, vol. 2, no. 1, pp. 77-104, 2009. 


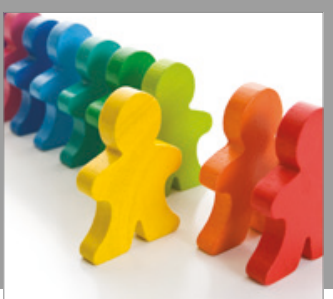

Autism

Research and Treatment
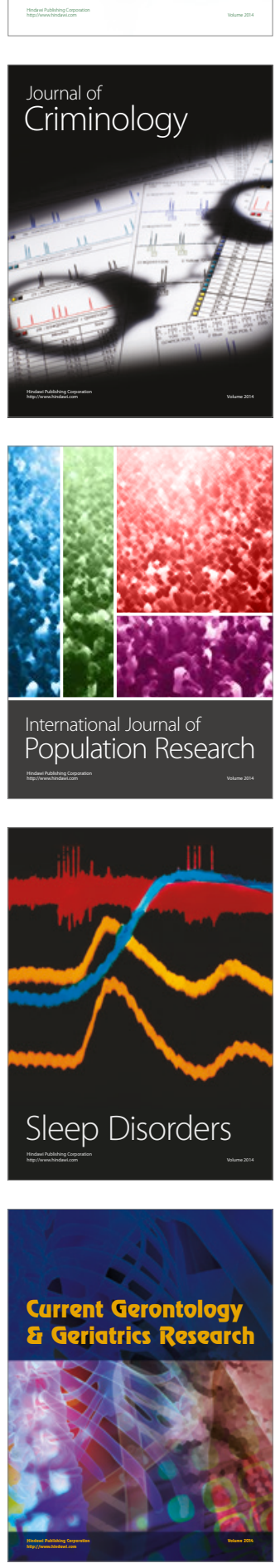

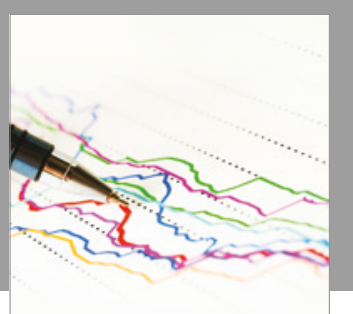

Economics

Research International

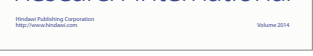

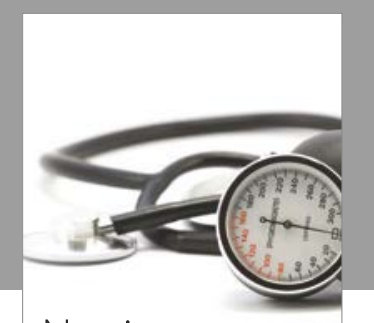

Nursing

Research and Practice

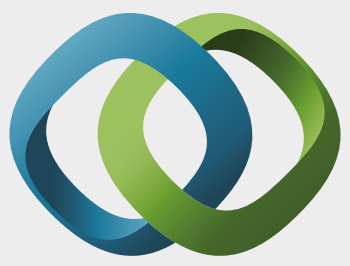

\section{Hindawi}

Submit your manuscripts at

https://www.hindawi.com
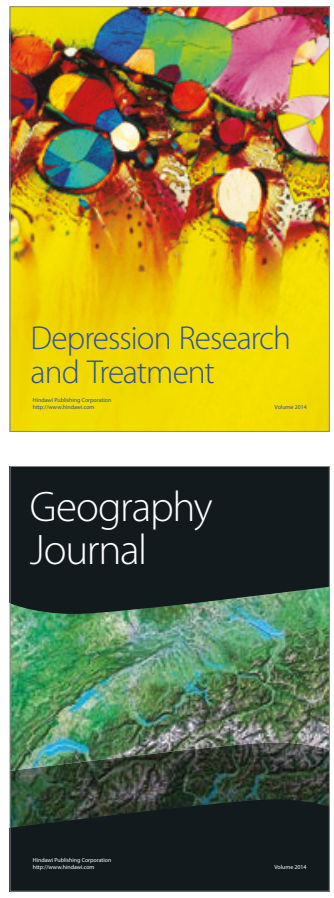
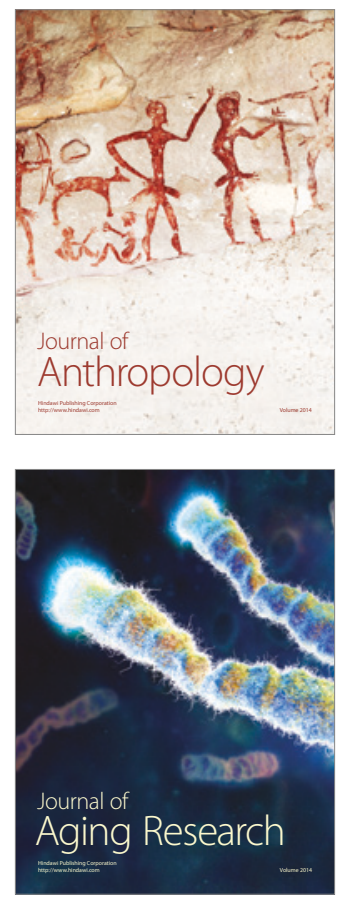
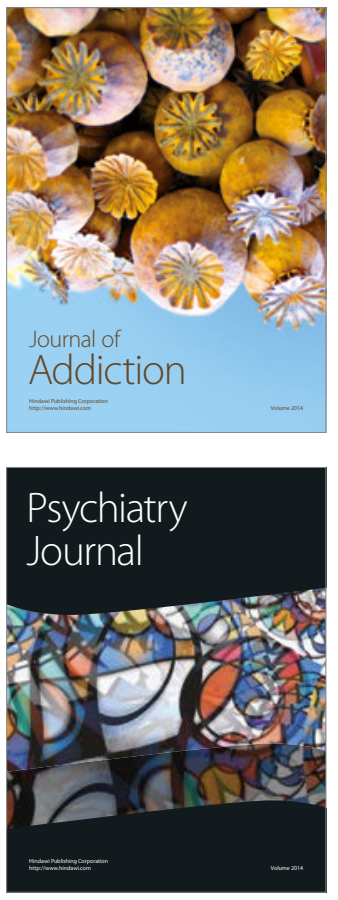

Child Development

Research

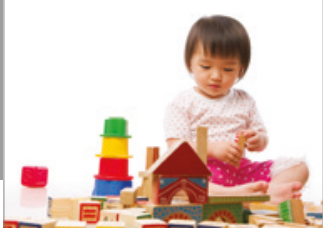

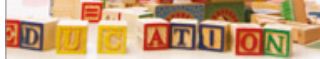
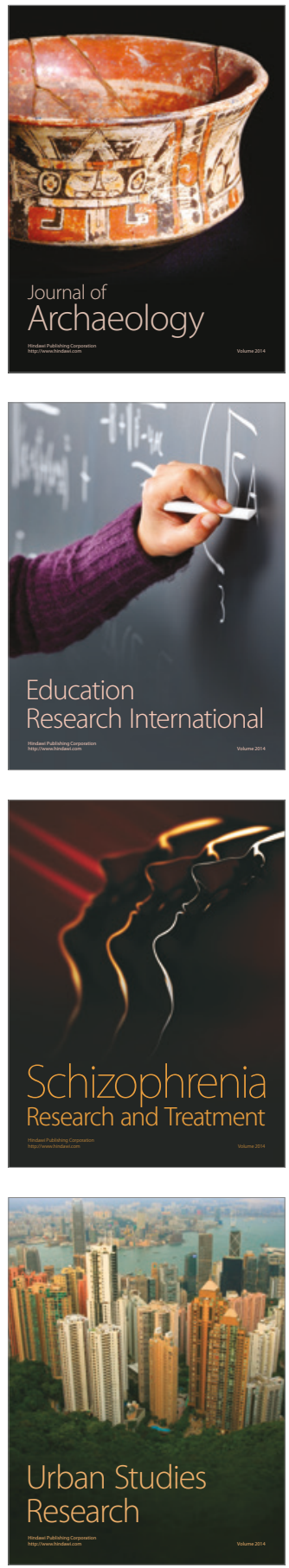